\title{
Abnormal open-hole natural gamma ray (GR) log in Baikouquan Formation of Xiazijie Fan-delta, Mahu Depression, Junggar Basin, China
}

https://doi.org/10.1515/geo-2018-0066

Received May 22, 2018; accepted Nov 12, 2018

\begin{abstract}
Based on large amounts of cores, open-hole conventional logs and mineral components analysis, abnormal natural gamma ray (GR) log showing high values in conglomerates and low values in fine-grained sediments, are described and explained in Baikouquan Formation of Xiazijie Fan-delta, Mahu Depression, Junggar Basin. After observing cores, normalizing the GR log and correcting depth errors between both, the GR log values of individual grain-sized lithology are extracted and counted. When grain-size decreases, the average GR values of different sized grains increase generally. The GR values of conglomerates are mostly between 50 and $80 \mathrm{API}$, while the values of fine-grains are mainly between 70 and 100 API. However, abnormal GR log features exist in the cores and wells of Baikouquan Formation prevalently. A great deal of high radioactive intermediate-acid volcanic minerals, such as volcanic tuff, felsite, andesite, granite, rhyolite, et al., distribute widely in the conglomerates, which results in abnormal high GR values in conglomeratic intervals. Low radioactive quartz components exit widely in high percentage in mudstones, which is the primary mineral explanation for the abnormal low GR values in reddish-brown siltstones and sandstones intervals.
\end{abstract}

Keywords: natural gamma ray log; Baikouquan Formation; Xiazijie Fan-delta; Mahu Depression; mineral components

\footnotetext{
^Corresponding Author: Rui Yuan: Key Laboratory of Exploration Technologies for Oil and Gas Resources (Yangtze University), Ministry of Education, Wuhan, Hubei, 430100, China; School of Information and Mathematics, Yangtze University, Jingzhou, Hubei, 434023, China; Email: yuanrui@yangtzeu.edu.cn Rui Zhu: School of Geoscience, Yangtze University, Wuhan, Hubei, 430100, China

Jianhua Qu, Xincai You, Jun Wu: Research Institute of Exploration and Development, Xinjiang Oilfield Company, PetroChina, Karamay, Xinjiang, 834000, China
}

\section{Introduction}

The natural gamma ray (GR, API) log, a necessary logging item in almost all petroleum open-holes, measures the total spontaneous radioactivity of the geological formations, and the radioactive elements are potassium (K), uranium (U) and thorium (Th). The total spontaneous radioactivity is very significant to indicate the lithology of deep burial rocks: gravelly and sandy sediments are less radioactive with low GR, while silt and clay are more radioactive with high GR generally $[1,2]$. However, the GR log may not follow the above law, and inverse property occasionally appears in the clastic rocks' petroleum basin, such as the Ordos, Hailar and Junggar Basins in China [3-6]. This abnormal GR logging phenomenon is also significant indication to identify hydrocarbon reservoirs and study stratigraphy. The natural gamma anomaly of the Ordos Basin directly resulted mainly from the tufaceous content increase [3, 4]. The factors affecting sandstones with high GR log values in Wunan depression of the Hailar Basin are tuffaceous matter, clay, oil, feldspar and calcium [5]. In the Permian Xiazijie Formation of the Junggar Basin, it is supposed that the abnormal high GR in the special lithologic sections mainly results from the redistribution of radioisotopes of the fragmental deposits within the formation [6]. However, previous literatures predominantly study the high GR in sandstones, hardly involving high GR in conglomerates and low GR in mudstones, which is the object of this paper.

Large scale proximal fan-deltas, named Xiazijie Fandelta, supplied by coarse-grained sediments and accumulated in shallow water lacus, developed in the Lower Triassic Baikouquan Formation on the north slope of the Mahu Depression, northwestern Junggar Basin, northwestern China [7-9]. The conglomerate formation contains newfound hydrocarbon reservoirs, which shows great petroleum resources potential $[10,11]$. With the deepen-

Yunfei Huang: School of Geoscience, Yangtze University, Wuhan, Hubei, 430100, China 
ing of exploration, more and more open-holes are logged and key wells are cored in oil-bearing intervals. The abnormal GR logging characteristic, high values in conglomerates and low values in fine-grained sediments, exits prevalently in the formation. Based on vast cores, logs and mineral components analysis, the goals of this study are to 1) describe the abnormal GR logging in different lithology and wells; 2) explain the mineral reasons for high GR in conglomerates and low GR in fine-grains.

\section{Geological setting}

The Junggar Basin, located in northwestern China (Figure 1a), is the second largest sedimentary basin and one of the most important petroliferous basins in this country (Figure 1b) [7-9]. With the Carboniferous Formation serving as basement, the basin is a large-scale intracontinental congruent basin. In the Late Paleozoic, JunggarTurpan Plate collided to Kazakhstan Plate, and subducted to the opposite side where formed the Zaire and Hala'alat Mountain on the hanging wall of the thrust fault. The collision started in Early Carboniferous, culminated in Later Carboniferous and Early Permian and receded during Middle Permian, which resulted in a foreland basin at the Mahu Depression (Figure 1c). It is surrounded by Wuxia and Kebai Fault-zone, and Zhongguai, Dabasong and Xiayan Uplift (Figure 1d). With the Hercynian and Indosinian movement, the foreland basin was in depression stage and received coarse sediments denuding from Zaire and Hala'alat Mountain since Later Permian [12-15]. Researchers consider that the formation is fed by the coarsegrained sediments transported form the fault and uplift zones, which developed proximal, shallow water, large coarse-grained fan-delta aprons on the slope of the Mahu Depression. They are mainly divided into six individual fan-deltas: Zhongguai, Karamay, Huangyangquan, Xiazijie, Xiayan and Dabasong Fan-deltas (Figure 1d) [7-9]. The Xizijie Fan-delta, on the north slope of depression, is the target research area of this study.

Since 2010, several conglomerate lithologic hydrocarbon reservoirs have been found in the Lower Triassic Baikouquan Formation of Mahu Depression, named $\mathrm{T}_{1} b$. With thickness of about 80-200 m, the Baikouquan Formation is divided into three members upwards, $\mathrm{T}_{1} b_{1}, \mathrm{~T}_{1} b_{2}$ and $\mathrm{T}_{1} b_{3}$. The $\mathrm{T}_{1} b_{1}$ and $\mathrm{T}_{1} b_{2}$, thick grayish-green and brown conglomerates imbedded thin brown mudstones, are major oil-bearing formations of the reservoirs. However, lithologies of $\mathrm{T}_{1} b_{3}$ are gray sandstones and graybrown mudstones, not rich in oil (Figure 1e) [16-18].

\section{Database and methodologies}

\subsection{Database}

As the key area of the Mahu Depression during the early exploitation stage, abundant essential cores, open-hole logs and mineral components analysis data are obtained in the Baikouquan Formation of Xiazijie Fan-delta. In total, $480.39 \mathrm{~m}$ cores from 14 wells (Figure 1d) are carefully observed and described in centimeter-scale, including the grain-size. The lithology is simply divided into two categories: conglomerate and fine-grain. Involving gravel and sand, the conglomerate includes boulder (Figure 2a), cobble (Figure 2b), coarse-pebble (Figure 2c), fine-pebble (Figure 2d), granule (Figure 2e), coarse-sandstone (Figure 2f), medium-sandstone (Figure $2 \mathrm{~g}$ ) and fine-sandstone (Figure $2 \mathrm{~h}$ ) $[19,20]$. The fine-grain is siltstone (Figure 2i) and mudstone (Figure $2 \mathrm{j}$ ). The interval with the same grainsize acts as one lithological layer, and there are 2872 layers. Sampled at each $0.125 \mathrm{~m}$ upward, all the cored intervals are measured by open-hole conventional logging suites, which correction for hole diameter has been made by logging operators. Besides borehole diameter (CALI, inch) and deep-investigation resistivity (RT, $\Omega \cdot \mathrm{m}$ ) logs, GR $\log$ is the dominated logging data. In order to understand the mineral components of conglomerates and mudstones, laboratory quantitative identifications clastic mineral components of 253 conglomeratic samples form 16 wells and X-ray diffraction of 18 mud samples from 7 wells are conducted. Section photos of gravels of which the grain-size is greater than $3 \mathrm{~cm}$ are used to support this paper.

\subsection{Method}

Description and explanation of the abnormal GR log in cores and wells in Baikouquan Formation require knowledge of primary geology and geophysics, which comprises four stages in this paper. The first stage, to get coring and logging data, three premised processes should be finished: 1) observing and recording the cores in core storage, which is the data source of the grain-size of sediments; 2) normalizing the GR logs in different wells, which would eliminate the differences among each open-holes; 3 ) correcting depth errors between cores and logs. Because of the different coring and logging time in the petroleum open-holes, it is necessary to remove the depth errors of several meters may be. Taking the logging depth as standard, the coring depth is moved up or down by contrasting the lithology to 

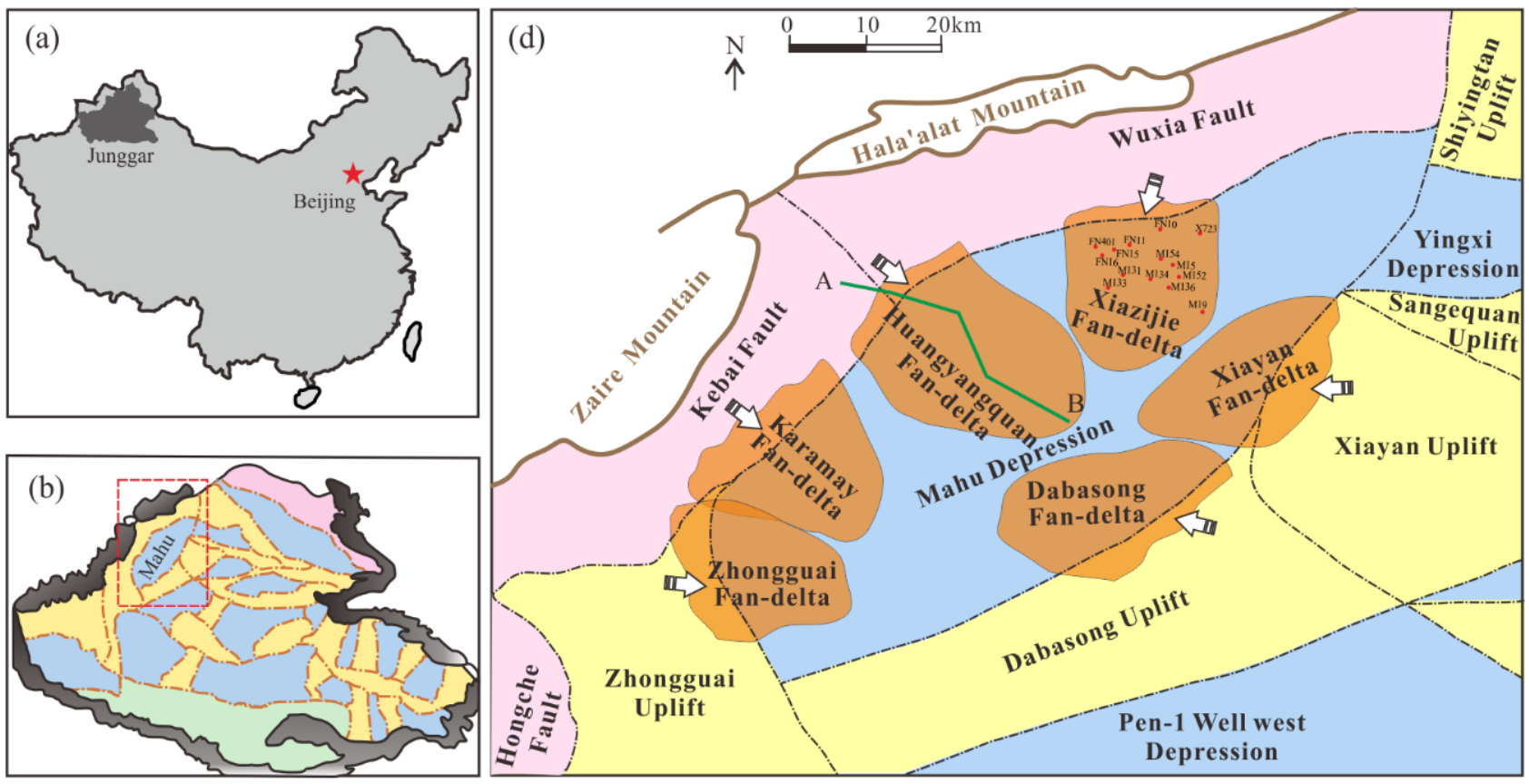

象)
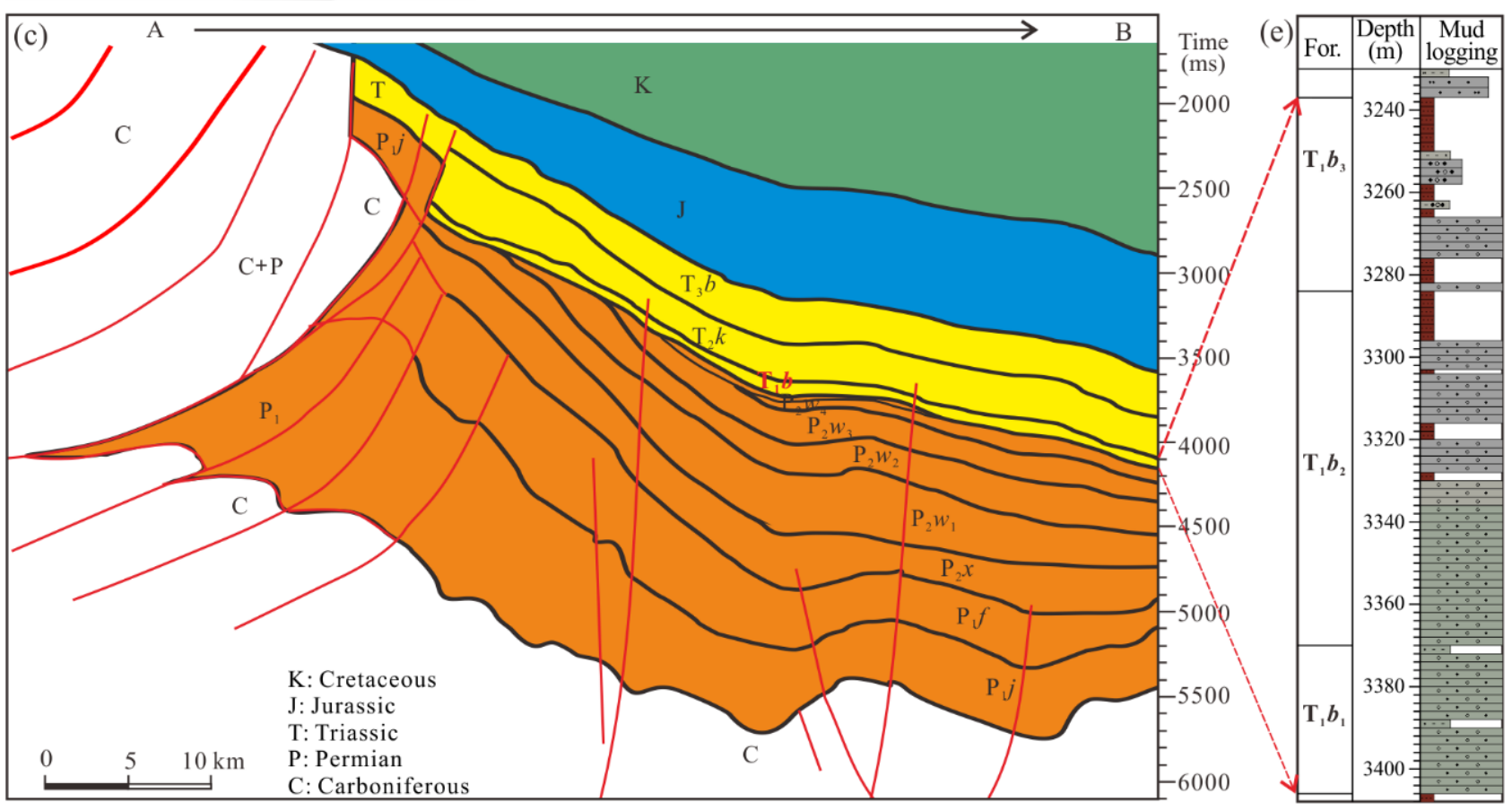

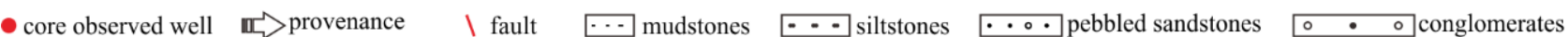

Figure 1: Tectonic and stratigraphy features of Mahu Depression. (a) Map of China. The Junggar Basin locates in northwestern China. (b) Tectonic map of Junggar Basin. Mahu Depression, red dashed rectangle marked, is in the northwestern margin of Junggar Basin. (c) Seismic explained profile from the faults to the slope. Carboniferous Formation cropped out at the northwestern Junggar Basin. (d) Six fan-delta aprons developed in the Lower Triassic Baikouquan Formation. The Xiazijie Fan-delta is the primary data sources for this paper. (e) Mud logging lithology in three members. Conglomerates are main lithology. 
(a)

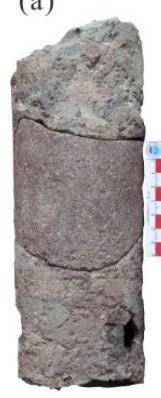

(b)

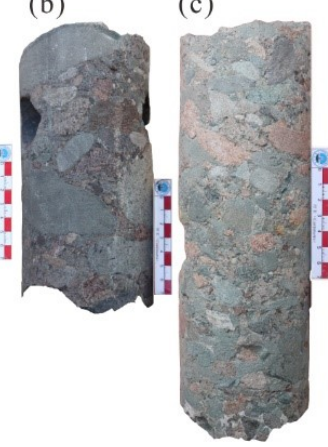

(d)

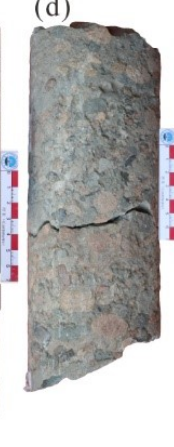

(e)

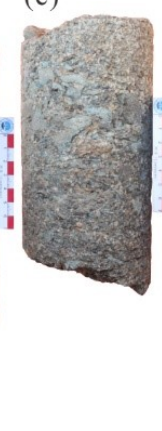

(f)

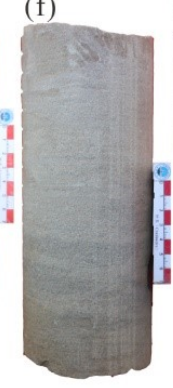

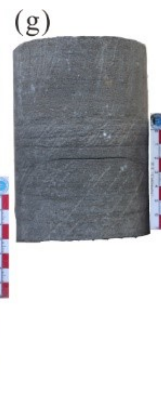

(h)

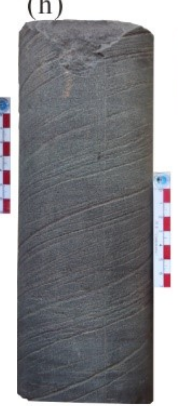

(i)

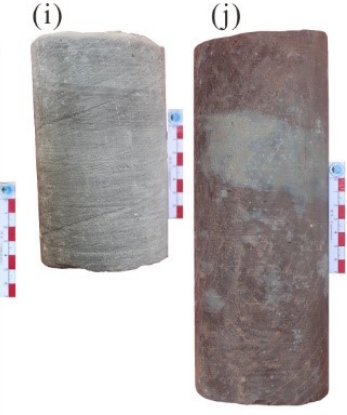

Figure 2: Core photos in different lithology of Baikouquan Formation of Mahu Depression. (a) Boulder (>128 mm), 17 lithological layers in total. (b) Cobble (32-128 mm), 378 lithological layers in total. (c) Coarse-pebble (16-32 mm), 813 lithological layers in total. (d) Fine-pebble $(8-16 \mathrm{~mm}), 789$ lithological layers in total. (e) Granule (2-8 mm), 465 lithological layers in total. (f) Coarse-sandstone, 128 lithological layers in total. (g) Medium-sandstone, 49 lithological layers in total. (h) Fine-sandstone, 59 lithological layers in total. (i) Siltstone, 59 lithological layers in all. (j) Mudstone, 123 lithological layers in total.
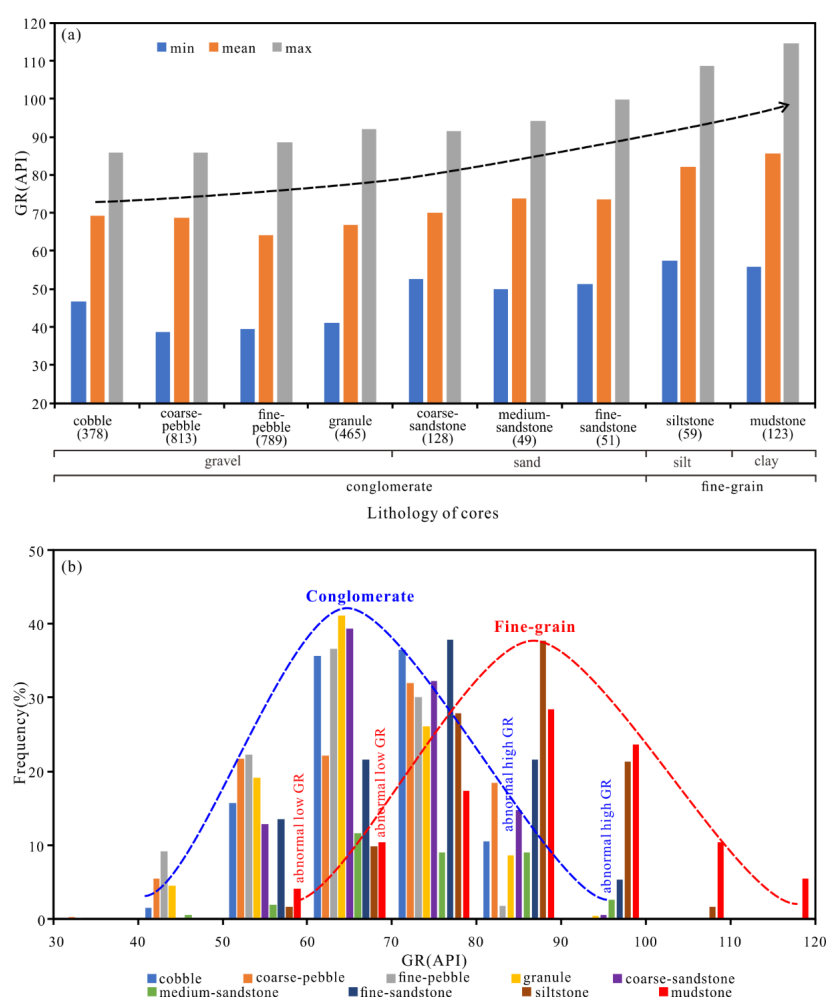

Figure 3: GR of different sized grains of cores. The lithology data come from the observation of cores, and the GR values are derived from the corrected open-hole logs. (a) Min, average and max GR of different sized grains. With the decrease of grain-size, these three parameters increase. The numbers in brackets are the number of lithological layers respectively. Due to the few layers, the boulders are not involved. (b) GR distribution of different sized grains. There are some high GR values in conglomerates and low ones in finegrains.

RT log: conglomerates are with high RT and fine-grains are with low RT values.
The second stage, to describe the abnormal GR log, involves 1) extracting the GR logging values of individual lithological layer; 2) calculating the minimum, average and maximum and counting frequency in different ranges for individual lithology; 3) finding the abnormal GR log in conglomeratic and fine-grained intervals in wells.

The third stage, to interpret the abnormal GR logging, includes 1) counting gravelly and sandy clastic mineral components to account for the high GR values in conglomerates; 2) counting mineral components of mudstones to infer the reason for the low GR values in fine-grained sediments.

\section{Results}

\subsection{GR of different lithology}

In sand-shale formation generally, the sandy intervals are in low radioactivity and high resistivity; in contrast, high radioactivity and low resistivity in the shaley intervals. The GR $\log$ is usually effective to identify the lithology. In order to study the GR values of different lithology in the Baikouquan Formation, the lithology of cores is accorded with the GR $\log$ in the wells. The mass data are counted in histogram plots in Figure 3. With the decrease of grain-size, the max and average GR values of different sized grains increase (Figure 3a). Although the GR of conglomerates are dominated between 50 and 80 API, and the values of finegrains are mainly between 70 and $100 \mathrm{API}$, there are some high values in the gavels and low ones in siltstones and mudstones (Figure 3b). These abnormal high or low values make it is impossible to unmix lithological information from GR log. 


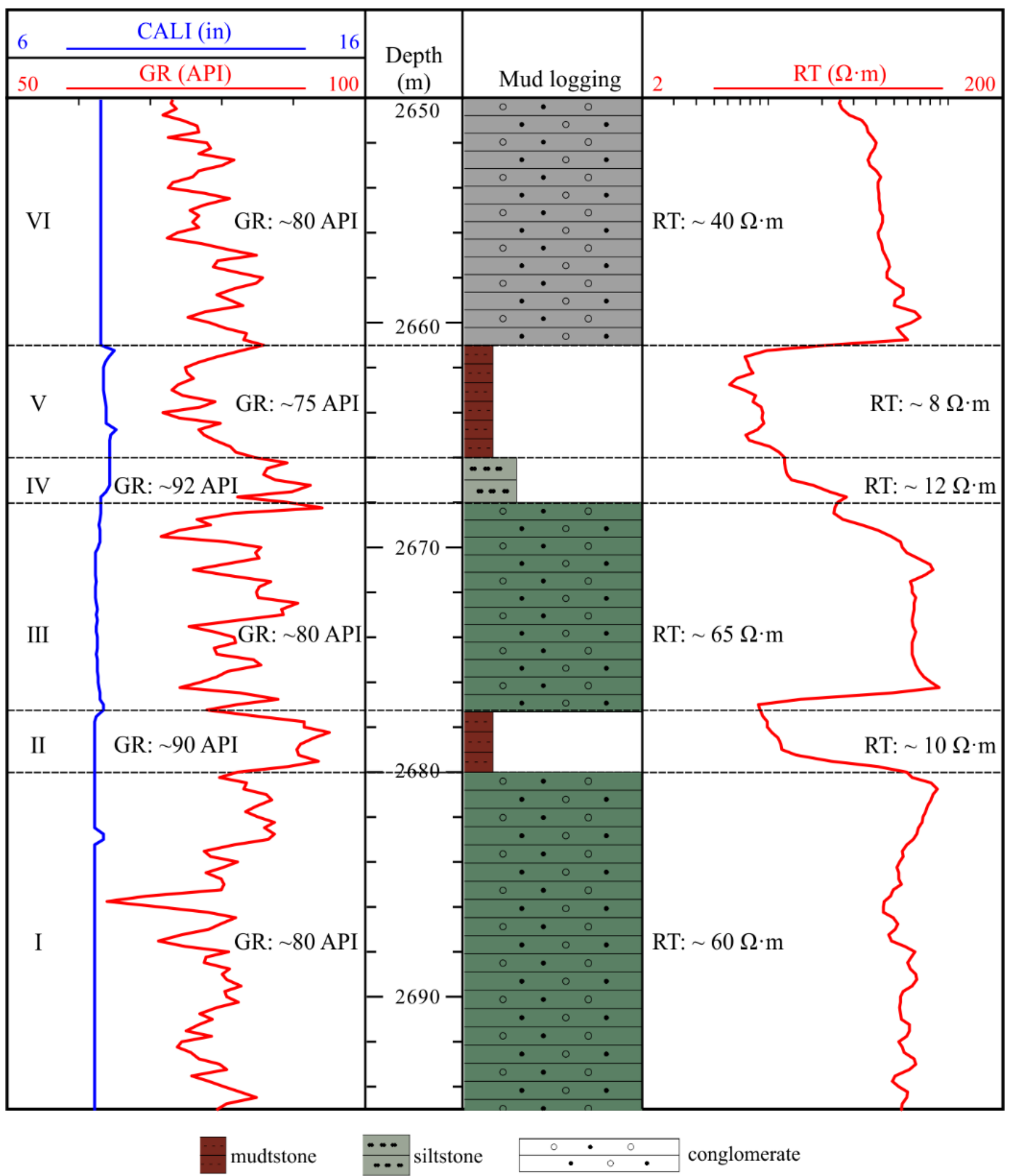

Figure 4: CALI, GR, RT log and mud logging lithology of Baikouquan Formation in Well X723. There are six lithological intervals identified from RT log and mud logging lithology. Although conglomerates and fine-grains can be distinguished by RT, their GR values are confused. 

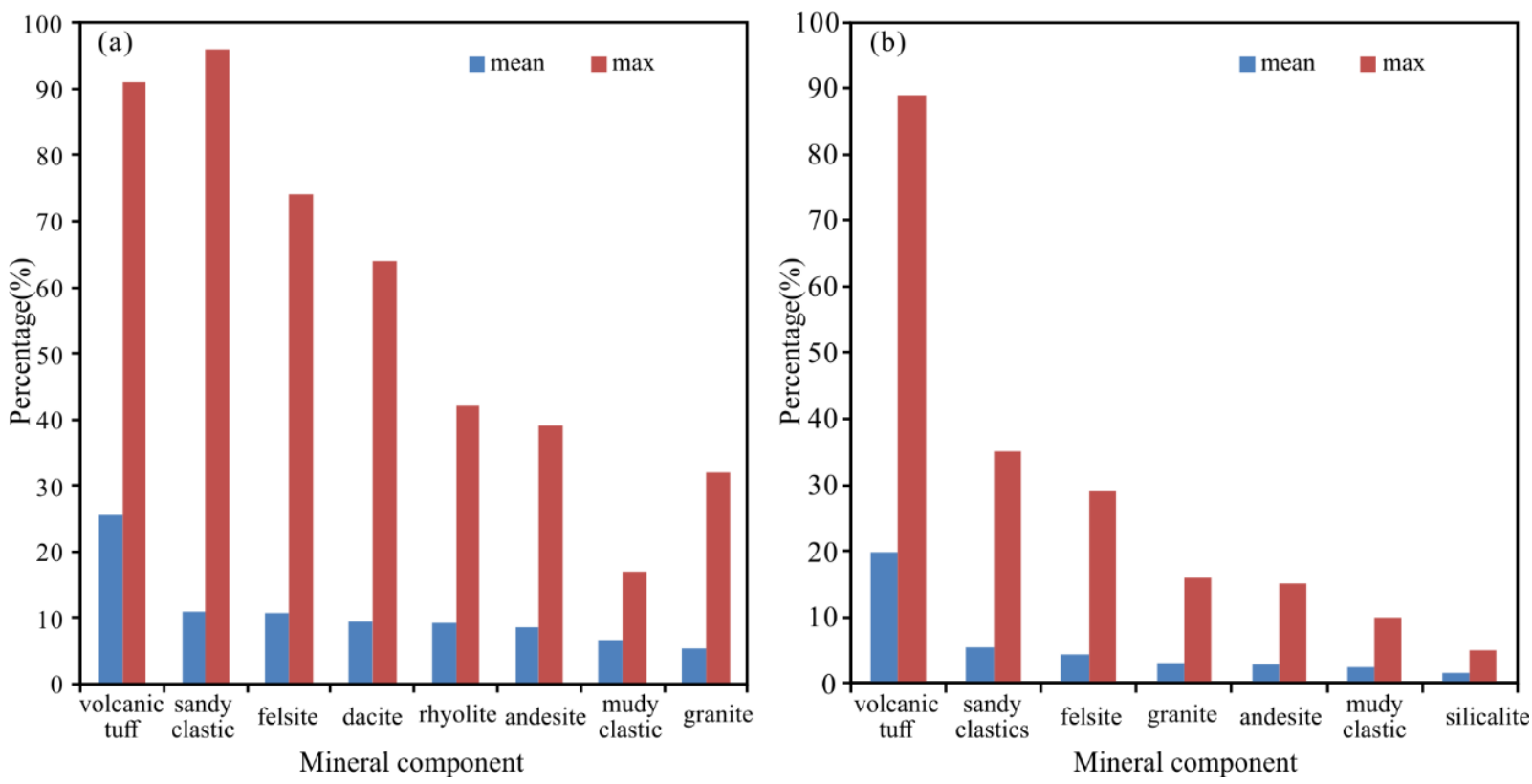

Figure 5: Mineral components percentage of conglomerate in Baikouquan Formation of Xiazijie Fan-delta. The data are from laboratory quantitative identification of clastic mineral components of 253 samples from 16 wells. (a) The mineral percentage components of gravels. The volcanic tuff, felsite, dacite, rhyolite, andesite and granite are widespread. (b) The mineral percentage components of sands. The volcanic tuff, felsite and granite are main minerals.

\subsection{GR in wells}

Because of the unusual rule of GR values in different lithology, the GR log is unsuccessfully used to do the lithological identification in wells as well. For the abnormal GR log, high values in conglomeratic intervals and low values in silts and clays exist widely in the Baikouquan Formation. Taking Well X723 as an example, the CALI, GR and RT log and mud logging lithology are shown in Figure 4. The first panel shows the CALI and GR logging curves in linear scale. The CALI almost in constant values, without enlargement in the borehole, which infers that the GR values are not affected by the borehole condition and could indicate the radioactive characteristics of circumferential formation reliably. The second panel shows the logging depth in meters. The third panel shows the mud logging lithology. During well drilling, the cuts of mud log could accurately identify the two categories lithology. The forth panel shows the RT logging curves in logarithmic scale.

From 2695 to $2650 \mathrm{~m}$, it can be divided into six lithological intervals upwardly: I) from 2695 to $2680 \mathrm{~m}$, conglomerates, GR about 80API and RT in $60 \Omega \cdot \mathrm{m}$; II) from 2680 to $2677.3 \mathrm{~m}$, mudstones, GR about $90 \mathrm{API}$ and RT in $10 \Omega \cdot \mathrm{m}$; III) from 2677.3 to $2668 \mathrm{~m}$, conglomerates, GR about 80 API and RT in $65 \Omega \cdot \mathrm{m}$; IV) from 2668 to $2666 \mathrm{~m}$, siltstones, GR about 92 API and RT in $12 \Omega \cdot \mathrm{m}$; V) from 2666 to $2661 \mathrm{~m}$, mudstones, GR about $75 \mathrm{API}$ and RT in $8 \Omega \cdot \mathrm{m}$; VI) from
2661 to $2650 \mathrm{~m}$, conglomerates, GR about $80 \mathrm{API}$ and RT in $40 \Omega \cdot \mathrm{m}$. It is known that the entrapped II has higher GR and lower RT than upper and lower conglomerates, which matches with the lithology. However, V has lower GR values and lower RT than upper and lower conglomerates, which is abnormal to the lithology. This abnormality confuses the adhibition of GR log. This demonstrates the abnormal GR values in proximal coarse-grained intervals of fan-delta in Mahu Depression, and may be explained by two causes: volcanic rocks in conglomerates and quartz of siltstones and mudstones, which will be discussed in the next section respectively.

\section{Discussions: Mineral reasons for abnormal GR}

\subsection{Mineral reason for high GR in conglomerates}

Mineral components are the elementary units of rocks, which determine the physical property, such as the radioactivity of the formations. According to the laboratory quantitative identification of clastic mineral components in 16 wells, it is known that the volcanic clastics exist in the gravels and sands (Figure 5). In the clasts of gravels 

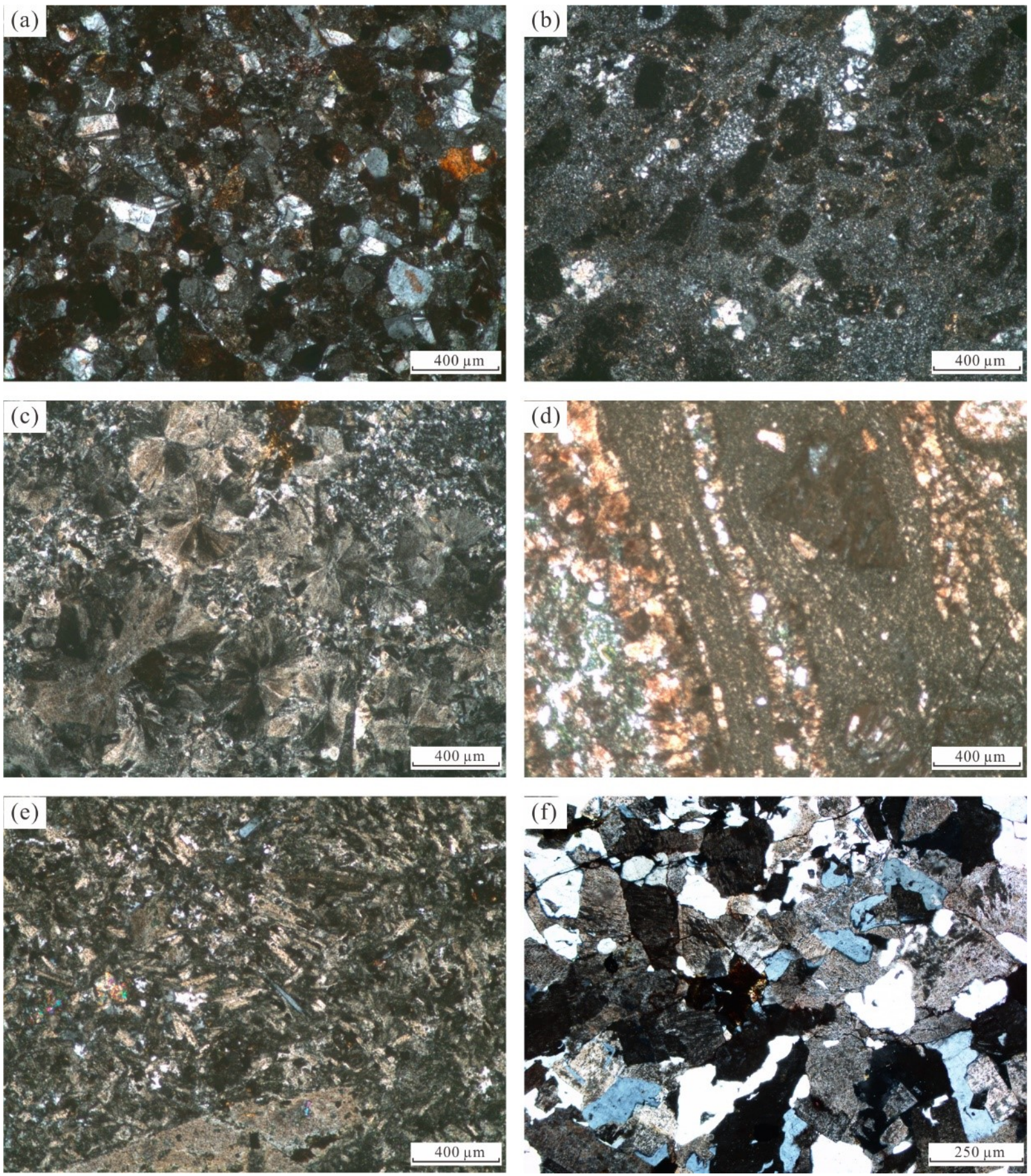

Figure 6: Section photos of conglomeratic mineral in Baikouquan Formation. The sections are from single gravel whose grain-size is greater than $3 \mathrm{~cm}$. (a) Debris-arkosic sandstone, cross-polarized light, $2089.4 \mathrm{~m}$ in Well X9. (b) Volcanic tuff, cross-polarized light, $2026.12 \mathrm{~m}$ in Well X9. (c) Felsite, cross-polarized light, $2342.62 \mathrm{~m}$ in Well X10. (d) Rhyolite, plane-polarized light, $2231.47 \mathrm{~m}$ in Well X10. (e) Andesite, cross-polarized light, $2060.12 \mathrm{~m}$ in Well X9. (f) Granite, cross-polarized light, $2439.95 \mathrm{~m}$ in Well X62.

(Figure 5a), the volcanic tuff is a dominative component, with average of $25.53 \%$ in 253 samples and up to $90 \%$ in one sample. The sandy clastics is the second component. The average percentage components of felsite, dacite, rhyolite, andesite and granite are ranged from $5 \%$ to $10 \%$. In the clastic of sand (Figure 5b), the similar volcanic clastics are prevalent as well. Therefore, besides the sandy minerals (Figure 6a), lots of intermediate-acid volcanic minerals: volcanic tuff (Figure 6b), felsite (Figure 6c), rhyolite (Figure 6d), andesite (Figure 6e), granite (Figure 6f) et al., 


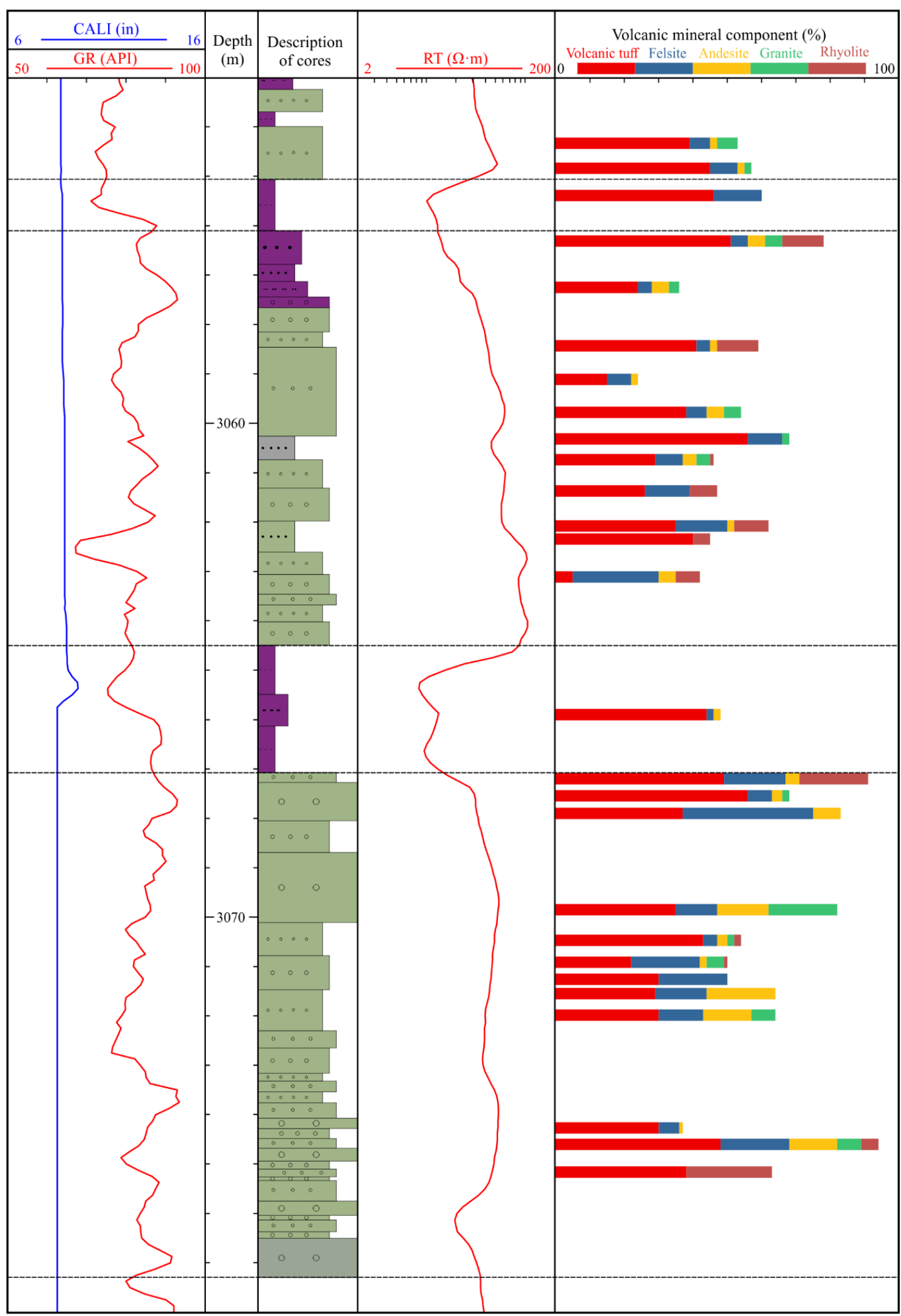

Figure 7: The logs, coring lithology and mineral component in Well M154, $T_{1} b_{2}$. According to the clastic laboratory quantitative identification, intermediate-acid volcanic minerals, such as volcanic tuff, felsite, andesite, granite, rhyolite, et al., are dominant mineral components in conglomerates with high GR. 


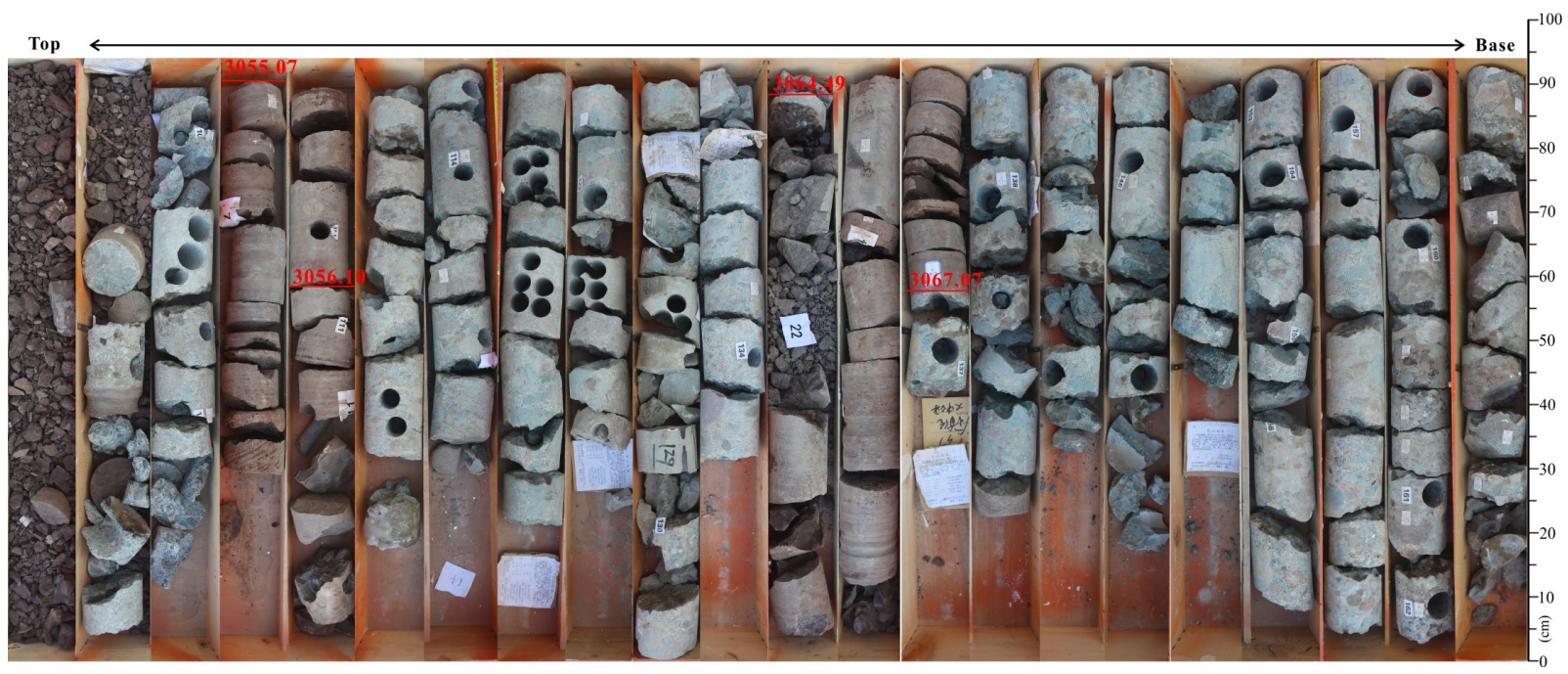

Figure 8: The photos of cores in the interval from 3053 to 3078 m, Well M154 in Figure 7. The conglomerates are greyish-green gravels, which include lots of igneous rocks. The color of siltstones and sandstones, 3067.07 to $3064.49 \mathrm{~m}$ and 3056.1 to $3055.07 \mathrm{~m}$, is reddishbrown.

are the main mineral components and widely exist in conglomeratic rocks of Baikouquan Formation.

Taking Well M154 for example, the coring lithology and open-hole logs of interval from 3053 to $3078 \mathrm{~m}$ are shown in Figure 7. The intervals from 3077.3 to 3067.07 $\mathrm{m}$ and 3064.49 to $3056.1 \mathrm{~m}$ are conglomerates, and from 3067.07 to $3064.49 \mathrm{~m}$ and 3056.1 to $3055.07 \mathrm{~m}$ are finegrains. The photos of corresponding cores are shown in Figure 8. The conglomerates are with high RT, and siltstones and mudstones are with low RT, which suggests normal electrical property of Baikouquan Formation. Different from RT, the GR log without obvious distinction between conglomerates and fine-grains. The last panel shows the volcanic mineral component percentages. It is shown that the volcanic tuff, felsite, rhyolite, andesite and granite are dominative mineral components, even up to $94 \%$ at $3074.60 \mathrm{~m}$.

The radioactive rule of volcanic rocks is proved by many literatures: K gradually increases from basic to intermediate and acid rocks, and $\mathrm{U}$ and $\mathrm{Th}$ are with very high percentages in the acid rocks [21,22]. Therefore, the intermediate-acid volcanic rocks are in high radioactivity. The mineral components such as volcanic tuff, felsite, andesite, granite, rhyolite, et al., are just intermediate-acid volcanic rocks. These highly radioactive igneous rocks transported to and accumulated on the slope of the depression and are the material of the gravels and sands of the Lower Triassic Baikouquan Formation, which may be the main mineral reason for abnormal high GR values in conglomerates [23, 24].

\subsection{Mineral reason for low GR in fine-grains}

In Well M154, according to the cores, the intervals from 3067.07 to $3064.49 \mathrm{~m}$ and 3056.1 to $3055.07 \mathrm{~m}$ are reddishbrown siltstones and sandstones (Figure 8) with low resistivity about $10 \Omega \cdot \mathrm{m}$. However, their GR is abnormally low with $85 \mathrm{API}$, which is closed to that of upper and lower greyish-green gravels. The Source-to-Sink system of the proximal fan-delta aprons of Mahu Depression are restricted at the front of the foreland basin [25]. With transportation distance in 30 kilometers (Figure 1d), these finegrained sediments mainly accumulated in the lacustrine, whose depositional process is the settling of suspended material in a standing body of water [26-28].

In order to understand the mineral components of sandstones, 18 mud samples from 7 wells are operated by $\mathrm{X}$-ray diffraction analyses. Experimental results show that the clay and quartz are two dominated mineral components, potassium feldspar and plagioclase are two minority mineral components. The clay components percentage is ranged from $38 \%$ to $71 \%$, and the quartz percentage is between $24 \%$ to $46 \%$, that is with little content difference from clay (Figure 9). The clay components are generally in high radioactivity, because the surface of clay particles adsorb abundant radioactive elements form the transportation and depositional environment. However, as one main mineral of sandstones, the quartz particles are usually low radioactive. High quartz components in the mudstones of the Lower Triassic Baikouquan Formation is the mineral reason for low high GR values in fine-grains possibly. 


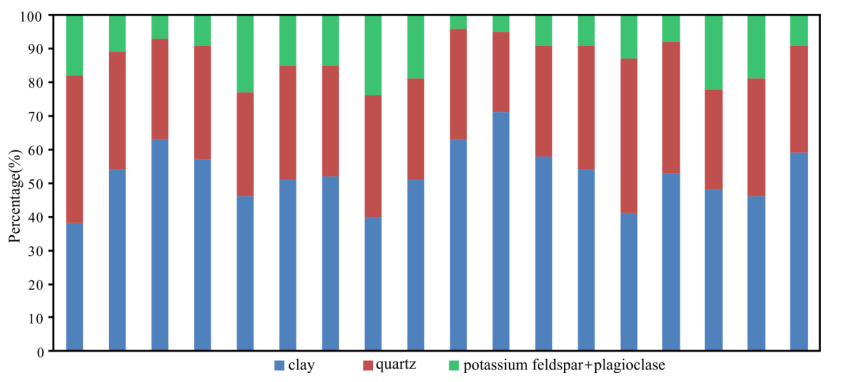

Figure 9: Mineral components percentage of mudstones. The data are from X-ray diffraction of 18 mud samples from 7 wells. The clay and quartz are the two dominate mineral components, and the quartz components percentage range from $24 \%$ to $46 \%$, in high values.

\section{Conclusions}

On the basis of abundant cores and conventional logs from Lower Triassic Baikouquan Formation of Xiazijie Fan-delta in Mahu Depression, GR logging characteristics of different lithology are summarized. With the decrease of grainsize, the GR average values of different sized grain increase generally. The GR of conglomerates are dominated between 50 and $80 \mathrm{API}$, while the values of fine-grains are mainly between 70 and 100 API. However, abnormal GR logging features, some high values in the conglomerates and low values in siltstones and mudstones, exist in the wells of Baikouquan Formation.

Based on the mineral components analyses of conglomerates and mudstones, there may be two mineral reasons for the abnormal phenomenon of GR in Baikouquan Formation. According to the laboratory quantitative identification of clastic mineral components, a mass of high radioactive igneous minerals, such as volcanic tuff, felsite, andesite, granite, rhyolite, et al., exist widely throughout the conglomerates, which results in abnormal high GR values in the conglomeratic intervals. According to the X-ray diffraction of 18 mudstones, low radioactive quartz components are in high percentage, which may lead to the abnormal low GR values in reddish-brown siltstones and sandstones intervals.

Acknowledgement: We are grateful to anonymous reviewers for their constructive reviews on the manuscript, and the editors for carefully revising the manuscript. This research is financially supported by Scientific Research Project of Hubei Provincial Department of Education (No. Q20181310) and Open Fund of Key Laboratory of Exploration Technologies for Oil and Gas Resources (Yangtze University), Ministry of Education (No. K2018-21). The supports are gratefully acknowledged.

\section{References}

[1] Schlumberger, Log interpretation principles/applications, Schlumberger, 1991.

[2] Darling T., Well logging and formation evaluation, Elsevier, 2005.

[3] Tan C. Q., Liu C. Y., Zhao J. L., Zhang R. R., Study on feature of high natural gamma anomaly and main controlling factors in Ordos Basin, Oil Geophysical Prospecting, 2007, 42(1), 50-56 (in Chinese with English abstract).

[4] Sun P., Zhang X. L, Guo L., Shen Y. B., Genesis of the sandstone with higher radioactivity and the qualitative evaluation of its reservoir property: taking Chang6 oil bearing strata in Zhidan Oilfield, Ordos Basin as an example, Journal of Xi' an Shiyou University (Natural Science Edition), 2010, 25(2): 18-21(in Chinese with English abstract).

[5] Yu Z. F., Cheng R. H., Zhao X. Q., Sun F. X., Xu Z. J., Shen Y. J., Genesis and identification of high gamma sandstone in the first member of Nantun Formation of Wunan depression in Hailar Basin, Journal of China University of Petroleum (Edition of Natural Science), 2012, 36(3), 76-83 (in Chinese with English abstract).

[6] Mao Z. Q., Shen B., Kuang L. C., Sun Z. C., Luo X. P., The special lithologic sections of Permian Xiazijie Formation in Junggar Basin: Geophysical characteristics and origin, Xinjiang Petroleum Geology, 2013, 34(1), 98-100 (in Chinese with English abstract).

[7] Yu X. H., Qu J. H., Tan C. P., Zhang L., Li X. L., Gao Z. P., Conglomerate lithofacies and origin models of fan deltas of Baikouquan formation in Mahu sag, Junggar basin, Xinjiang Petroleum Geology, 2014, 35(6), 619-627 (in Chinese with English abstract).

[8] Zou N. N., Shi J. A., Zhang D. Q., Ma C. Y., Zhang S. C., Lu X. C., Fan delta depositional model of Triassic Baikouquan formation in Mabei area, NW Junggar basin, Acta Sedimentologica Sinica, 2015, 33(3), 607-615 (in Chinese with English abstract).

[9] Tang Y., Xu Y., Qu J. H., Meng X. C., Zou Z. W., Fan-delta group characteristics and its distribution of the Triassic Baikouquan reservoirs in Mahu Sag of Junggar Basin, Xinjiang Petroleum Geology, 2014, 35(6), 628-635 (in Chinese with English abstract).

[10] Kuang L. C., Tang Y., Lei D. W., Wu T., Qu J.H., Exploration of fancontrolled large-area lithologic oil reservoirs of Triassic Baikouquan formation in slope zone of Mahu depression in Junggar basin, China Petroleum Exploration, 2014, 19(6), 14-23 (in Chinese with English abstract).

[11] Zhi D. M., Discovery and hydrocarbon accumulation mechanism of quasi-continuous high-efficiency reservoirs of Baikouquan Formation in Mahu Sag, Junggar Basin, Xinjiang Petroleum Geology, 2016, 37(4), 373-382 (in Chinese with English abstract).

[12] Meng Q. F., Xu Z. H., Xu H. M., Liu W. F., Wang G. H., Shang J. L., Qiu J. P., Characteristics and controlling over reservoir accumulation of tear fault in foreland thrust belt of Baikouquan area in the northwestern margin of Junggar Basin, Journal of China University of Petroleum, 2008,32(5), 18-21 (in Chinese with English abstract).

[13] Kuang J., Qi X. F., The structural characteristics and oilgas explorative direction in Junggar Foreland Basin, Xinjiang PetroleumGeology, 2006, 27(1), 5-9 (in Chinese with English abstract).

[14] Liu H., Chen J. P., Regularities of Triassic-Jurassic structural movements controlling fans development in the Wuxia thrust 
belt of Junggar Basin, Geotectonica et Metallogenia, 2010, 34(2), 204-215 (in Chinese with English abstract).

[15] Shao Y., Wang R. F., Zhang Y. Q., Wang X., Li Z. H., Liang H., Strike-slip structures and oil-gas exploration in the NW margin of the Junggar Basin, China, Acta Petrolei Sinica, 2011, 32(6), 976-984 (in Chinese with English abstract).

[16] Yuan R., Zhang C. M., Qu J. H., Wu T., Sun Y. Q., Zhu R., Lithological identification of conglomerate using resistivity imaging logging: A case of Baikouquan formation in Mahu depression, Junggar Basin, Northwest China, International Journal of Earth Sciences and Engineering, 2016, 9(5): 2268-2272.

[17] Yuan R., Zhang C. M., Tang Y., Qu J. H., Guo X. D., Sun Y. Q., Zhu R., Zhou Y. Q., Utilizing borehole electrical images to interpret lithofacies of fan-delta: A case study of Lower Triassic Baikouquan Formation in Mahu Depression, Junggar Basin, China, Open Geosciences, 2017, 9(1): 539-553.

[18] Yuan R., Zhu R., Qu J. H., Zhang L., Wu J., Wang Z. L, Pan J., Division method of double property lithofacies based on microresistivity imaging logs: A case study of Baikouquan formation in Mahu sag, Junggar basin, Journal of Northeast Petroleum University, 2018, 42(1), 14-23 (in Chinese with English abstract).

[19] Zhang C. M., Wang X. L., Zhu R., Qu J. H., Pan J., An Z. Y., Lithofacies classification of Baikouquan formation in Mahu sag, Junggar basin, Xinjiang Petroleum Geology, 2016, 37(5), 606-614 (in Chinese with English abstract).

[20] Qu J. H., Zhang L., Wu J., You X. C., Characteristics of sandy conglomerate reservoirs and controlling factors on physical properties of Baikouquan formation in the western slope of Mahu sag, Junggar basin, Xinjiang Petroleum Geology, 2017, 38(1), 1-6 (in Chinese with English abstract).

[21] Kou Y., Shi Y. M., Li B. R., Qin X. S., Wang L. and Li X. M., The complex lithology rock-electricity features of volcanic rocks in Kelameili gas field, Acta Petrologica Sinica, 26(1), 291-301 (in Chinese with English abstract).
[22] Li N., Tao H. G. and Liu C. P., Well logging interpretation theory, approach and application for acid volcanic rocks, Petroleum Industry Press, Beijing, 2009, 12-18 (in Chinese).

[23] Zhao F., Depositional system and reservoir characteristics of Baikouquan formation of Triassic of Wu36 well block in Wuerhe oilfield, Xi'an, Shanxi, Northwest University, 2010 (in Chinese with English abstract).

[24] Zhou J. L., Wang Z. J., Ding C., Wang G. W., Song G. J., Su C. Q., High GR glutinite feature and micro-sedimentary facies in Wuerhe oil-field, Junggar Basin, Acta Sedimentologica Sinica, 2014, 32(4), 734-743 (in Chinese with English abstract).

[25] Yuan R., Zhu R., Qu J. H., Wu J., You X. C., Sun Y. Q., Zhou Y. Q., Utilizing Integrated Prediction Error Filter Analysis (INPEFA) to divide base-level cycle of fan-deltas: A case study of the Triassic Baikouquan Formation in Mabei Slope Area, Mahu Depression, Junggar Basin, China, Open Geosciences, 2018, 10(1), 79-86.

[26] Martins-Neto M. A., Lacustrine fan-deltaic sedimentation in a Proterozoic rift basin: the Sopa-Brumadinho Tectonosequence, southeastern Brazil, Sedimentary Geology, 1996, 106, 65-96.

[27] Bourquin S., Rigollet C., Bourges P., High-resolution sequence stratigraphy of an alluvial fan-fan delta environment: stratigraphic and geodynamic implications - An example from the Keuper Chaunoy Sandstones, Paris Basin, Sedimentary Geology, 1998, 121, 207-237.

[28] Fisher J. A., Nichols G. J., Waltham D. A., Unconfined flow deposits in distal sectors of fluvial distributary systems: Examples from the Miocene Luna and Huesca Systems, northern Spain, Sedimentary Geology, 2007, 195(1-2), 55-73. 